22 Dische S. Chemical sensitizers for hypoxic cells: a decade of experience in clinical radiotherapy. Radiother Oncol 1985;3:97-115.

W Waserman TH, Urtasun RC, Halsey J, Noll L, Hancock S, col. Final report of the phase I trial of the hypoxic cell radiose et al. Final report of the phase I trial of the hypoxic cell radiosensitiz SR-2508 (ethanidazole). Radiation Therap

24 Chaplin DJ, Olive PL, Durand RE. Intermittent blood flow in a murine tumor: radiobiological effects. Cancer Res 1987;47:597-601.

25 Horwich A. Combined radiotherapy - chemotherapy in clinical practice. In Steel GG, Adams GE, Horwich A, eds. The hiological basis of radiotherapy. Amsterdam: Elsevier, 1989:279-89.

26 Steel GG. The search for therapeutic gain in the combination of radiotherap and chemotherapy. Radiother Oncol 1988;11:31-53.

27 Medical Research Council Leukaemia Committee. Treatment of acute lymphoblastic leukaemia: effect of "prophylactic" therapy against central nervous system leukaemia. BMF 1983;ii:381-4.

28 Horwich A, Peckham MJ. Combined chemotherapy and radiotherapy in the management of adult Hodgkin's disease: indications and results. In: Selby P, McElwain TJ, eds. Hodgkin's disease. Oxford: Blackwell Scientific, 1987:250-68.

29 Cummings B, Keane TJ, Thomas GM, Harwood AR, Rider WD. Results and toxicity of the treatment of anal canal carcinoma by radiation therapy or radiation therapy and chemotherapy. Cancer 1984;54:2062-8.

30 Dobbs HJ, Hushand JE. Computed tomography for radiotherapy planning. Appl Radiol 1984;13:51-61.

31 O'Connell MEA, Flower MA, Hinton PJ, Harmer CL, McCread VR Radioiodine dose assessment. Dose-response in differentiated thyroid carcinoma using quantitative scanning and.PET. Radiother Oncol (in press)

32 Emami B, Lyman J, Brown A, et al. Tolerance of normal tissue to therapeutic irradiation. Int f Radiat Oncol Biol Phys 1991;21:109-22.

33 Tait D. Conformal therapy. Brf Cancer 1990;62:702-4

34 Tait D, Nahum A, Southall C, Chow M, Yarnold JR. Benefits expected from simple conformal radiotherapy in the treatment of pelvic tumours. Radiother Oncol 1988;13:23-30.

35 Williams MV, Denekamp J, Fowler JF. Dose response relationships for human tumours: implications for clinical trials of dose modifying agents. Int 7 Radiat Oncol Biol Phys 1984;10:1703-7.

36 Suit H. Potential for improving survival rates for the cancer patient by increasing the efficacy of treatment of the primary lesion. Cancer 1982;50 1227-34.

37 Horwich A. The future of radiotherapy. Radiother Oncol 1990;19:353-6.

\title{
Letter from Poland
}

\section{Post-totalitarian medicine}

\author{
Karin Chopin
}

This is the last of three articles examining health issues in Poland
There is no way of knowing what democracy will end up looking like in Poland but here are some glimpses of it now.

Ania, a 45 year old obstetrician I met on my travels with the itinerant Polish deputy minister of health, Zbigniew Halat MD, invited me to her home to meet a group of people involved in various aspects of health care. Sitting round her kitchen table, they unfolded their lives for me.

\section{Temptations of corruption}

The young psychiatrist: "People have so much initiative in this country. This is our capital-but it must be exploited appropriately."

The head of a public health laboratory: "Our records aren't that good, I'll admit, but who are the World Bank, the World Health Organisation, or the Americans to come preaching to us? Rather a life in a Gdansk housing estate than a life in the Bronx. ... And as for Sweden, people there are so bored that they all want to commit suicide."

The matron in charge of a nursing home: "We experienced the second world war and ever since, like most of the people in eastern Europe, I think we behave as if it never ended. Maybe this is why I am never really surprised that even 45 years afterwards there is still a lack of medicines, bandages, syringes. ..."

"If the new laws permitting private clinics are not encouraged, one can safely predict that our citizens will continue to resort to the time honoured Polish custom of illegal payoffs-bribing doctors and nurses," the ward sister said. The corruption of the medical services in Poland is an undeniable social fact - "It's so much easier to bribe women doctors than men doctors," a friend from Warsaw once admitted. "How much more natural to give presents to a lady."

"We don't want to be like this," a young doctor protested, "but it is the system that forces us to. We are state employees, but the state is bankrupt and tells us to go and earn privately. You start out with noble intentions but then you find yourself having to succumb to the temptations of corruption just to survive.' (Doctors currently earn $72 \%$ of the average national wage.) The newly appointed Polish minister of health, Dr Marian Miskiewicz, acknowledges that doctors accept bribes, especially in surgery, orthopaedics, and obstetrics, but he does not agree it is a common practice. A Polish sociologist elaborated: "The trouble is that the health care system, basically designed in the early ${ }^{\prime} 50 \mathrm{~s}$, remains a highly centralised and rigid structure. The more rigid the structure and functions of a given institution, the more likely is a split between formal and informal structures."

The hospital manager: "Do you know that ambulances are called out four times more frequently in Poland than in the developed countries of western Europe?" (The minister of health had recently publicly deplored the disgracefully wasteful deployment of ambulances in Poland.) "A woman has a temperature and cannot be bothered to go down to the clinic, so she calls an ambulance. And then we don't have enough petrol to send out for the chap who's having a heart attack." Here I could not help interjecting: "But people in the West think of you also as a developed country." "What do you mean, 'developed'?" one of the company retorted in the fashionably self deprecat ing manner of the postcommunist era. "We're lagging at least 20 years behind you. Don't you realise that in the past decades our principal slogan was building communism, our main priority defence... an issue such as personal health was about number 193 on our list of national priorities."

I mention the young man I had seen on the way there, crouched in the doorway, covered with only a blanket to protect him from the falling snow. "I have AIDS, please help me," said his sign. "It is only a miracle that there are not more beggars, what with more than half of the working population living at the edge of poverty," explained Father Roman Indrzejczyk, pastor to the medical profession in Warsaw.

"And then, in the midst of all this, our anti-choice nationalist government is threatening our right to abortion and telling us to multiply, to given birth to more Poles!" Ania, our host, was enraged by officials in the Ministry of Health, who refuse to disseminate any birth control information, and accused them, the Chamber of Physicians, and the gynaecology establishment of being "criminals" for allowing abortions to proliferate by opposing birth control programmes. "They should be serving time," she said, "for the harm they're doing to women's health. And apart from anything else, abortion is a costly method if used as a primary resource of contraception as it is in Poland." She is involved in a passionate crusade to lower the
BS2 8ND

Karin Chopin, medical student

BMF 1992;304: 1557-60 


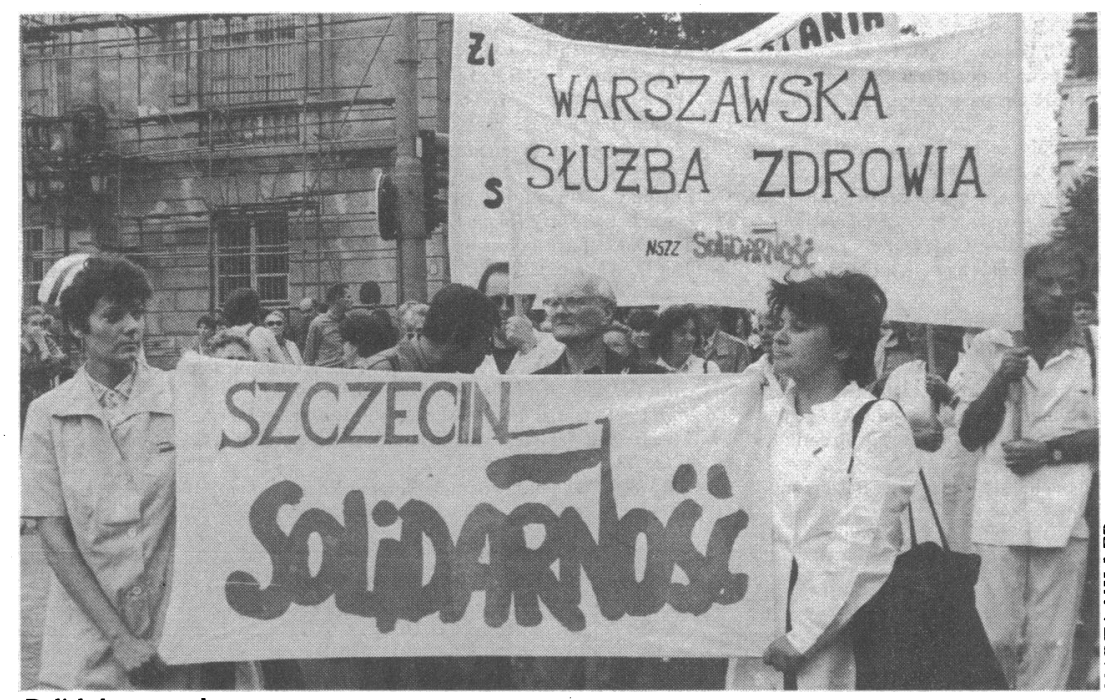

Polish doctors and nurses protesting in Warsaw nation's appalling abortion rate. "Do you really want to know why so many of our doctors oppose birth control? In this country much shame is still attached to abortion, and our doctors oppose birth control because they make so much money out of private abortions [many women apparently choose this alternative to ensure proper anaesthaesia and anonymity]. We've been brought up to look on abortion as a necessary evil, and on birth control devices as harmful and unreliable.... We are so backward that half our condoms break upon first use."

There were, inevitably, some negative comparisons with the West, which tended to centre on Westerners' "sad over-individualism." "Our sense of community is fast declining, but you're still far more solitary and lonely than we are.... Over here if you fell sick in the street you'd immediately be taken into someone's house; over there, no one would know the difference if you died. And you put all your old people into homes for the elderly, which would be unthinkable to us, even if we had many such homes. Old age is celebrated in our country, rather than regretted." But someone else countered this: "Our family ties are sometimes too strong, and our living conditions kill all privacy-I could do with a little bit of loneliness sometimes, maybe even some of your Western alienation."

\section{Health care reforms}

"You are a fortunate young woman," Dr Andrzej Wojtczak, the distinguished professor of public health medicine at the Medical Postgraduate Centre in Warsaw, told me. "Foreigners usually only meet a very select bunch of English speaking people in our country. Do not be sparing in your criticism; you have seen so much. The trouble here is that knowing and accepting have become the same thing, and it takes an external voice to shake us. The politician cannot be pessimistic - even if a good dose of introspective gloom might be the only precursor to radical change. ... We know the patient is sick, but sometimes you need to borrow the eyes of a friend to see yourself."

The avuncular Professor Wojtczak was an island of calm in the turbulent waters I had found myself tossed into in Poland. Every couple of weeks I would collapse into one of the comfortable chairs in his office, tea and cakes would immediately appear, and, with infinite patience and kindness, the good professor, who, as the principal author of the country's new national health policy, had far more important things to do, would help me get all that I had seen and heard into perspective. He attributed the current predicament of the Polish health service to years of excessive centralisation and bureaucracy; to the high priority put on developing the production of materials and consequent devaluing of health, and of non-manual workers including health workers; and to the informal health care system based on privilege that arose alongside the formal system. "Now add to that the present lack of discipline among civil servants, the arbitrary decision making that goes on at all levels, the country's outdated laws, the continuing corruption of many officials, and the fact that in the past many health statistics were either kept secret or were non-existent or unreliable, and perhaps you can begin to understand why you are finding reporting on our health service such a challenge."

Professor Wojtczak summarised for me the underlying trends of the Polish health care reforms now either in force or under discussion: decentralisation to a local level; increased cost consciousness; a diversification of health care funding sources; a shift of responsibility to the patient; and the re-education of about $40 \%$ of doctors to create general practitioners, and the introduction of the concepts of general practice and health promotion into medical education. "The latter will be our most difficult task," he explained, "for the concept of general practice is completely alien here. And since we have very few resources, the government has not got enough money for health promotion. What exists is totally uncoordinated, and anyway, the whole concept is bedevilled by the problem of lack of credibility of the source-politicians have been lying for so long that the general public distrusts them and is not receptive to health education messages. The transition to a more effective and efficient health service will be difficult without a restructuring of the whole socialist legacy," he admitted. "And it will take so long to change habits. For even though the socialist states have fallen apart, many of the old habits haven't. They are still with us, built in like a microchip.... Although Poland is currently leading the countries of central and eastern Europe in the field of health reform," he told me proudly, "the faltering progress it has made in this field stands both as an example and a warning for those emerging nations to our east about to undertake the same adventure."

\section{Need for a change of heart}

Sadly, the Polish people are not a healthy lot. Moreover, Poland is experiencing increasing problems meeting the health care needs of its population. The key problems are lack of money, inefficiency in the health service, profound demoralisation among health professionals, and a predominant reliance on public funds for the system's revenue. Since the 1970s the health of the Polish people has deteriorated and the increases in life expectancy achieved during the 1950s and 1960s have actually been reversed (figure). Mortality among men over 30 is now greater than 10 years ago, and $20 \%$ fewer men in Poland can expect to live to the age of 65 as compared with men of the same age in the Netherlands or Japan. Infant mortality is higher in Poland than in most European countries; although it declined from 111 deaths/1000 live births in 1950 to $15 \cdot 9 / 1000$ in 1989 (as compared with the Organisation for Economic Cooperation and Development range of $5 \cdot 0-14 \cdot 2$ ), the rate of decline has slowed. The incidence of hepatitis B infection is 10 times greater than the European average. Poland's tuberculosis problem is still the most severe in Europe, and this disease remains the single most common cause of death of infectious aetiology in the country, although the number of deaths from tuberculosis has decreased drastically to $49 / 100000$ (as compared with $9 / 100000$ in the United States). The number of disabled people among the working population is increasing: this may 


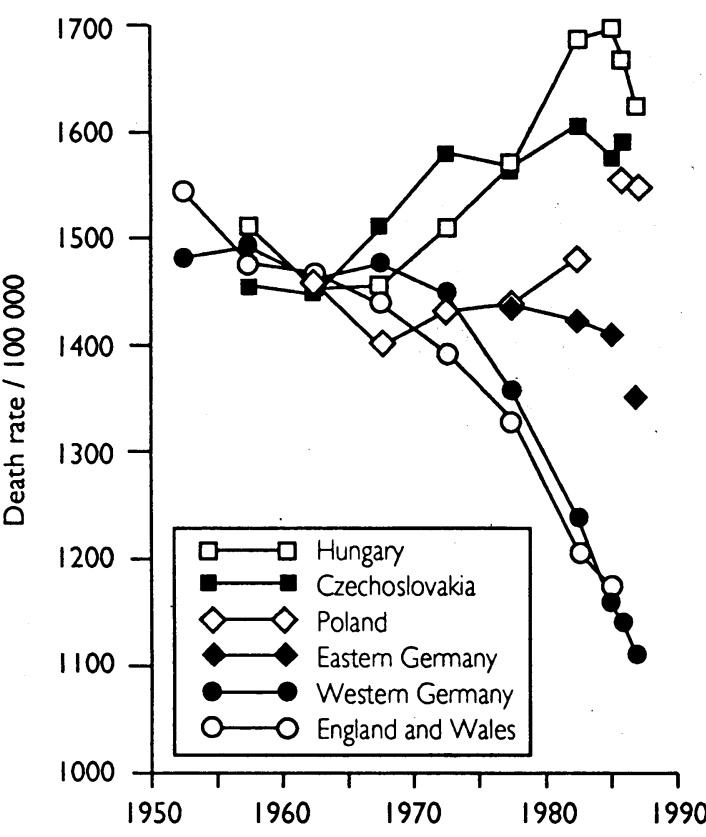

be linked to the fact that about $20 \%$ of the work force is exposed to a hazardous working environment. It is differences in lifestyle and harmful health practicessuch as unhealthy eating habits, smoking (Poland has Europe's highest growth rate in the incidence of lung cancer), excessive drinking, a sedentary way of life, and, to some extent, accidental injury and deathsthat are held responsible for this remarkable divergence between eastern and western Europe (data from the Polish Ministry of Health).

Although the programme of radical reform launched by the new Polish government to remedy the major ills of Polish society applies equally to the Polish health care system, the government has so far paid little attention to health problems, as it has been mainly concerned with improving the country's desperate economic situation and establishing a new political system. "We have already wasted two years arguing," Dr Miskiewicz admitted bitterly in a recent newspaper interview. In common with most people in the Ministry of Health, he is seized by the urgency to reorient Poland's health policy to address the radically altered epidemiological situation that has emerged in the past two decades. But he concedes that improvement in health care will be a prolonged process, as much a result of a change of heart as of a change of policy. "People have to understand that, although the system has changed for the better, they will get less for some time to come.... There is no reaching out for simple answers provided by quick fix demagogues.... The health care system needs large infusions of funds but money alone will not solve our problems."

\section{The "Polish factor"}

Indeed, the formidable problems facing Polish medicine are also those facing Polish society: the solution to the former cannot be achieved without that of the latter. Unfortunately, Solidarity tactics of political revolution remain the only tested method of achieving change. The Poles seem to be having great difficulty in making the necessary management changes to respond to the new opportunities. "At every level, people simply don't know how to take decisions and act upon them," a frustrated Ministry of Health official complained to me. "And if they do, they do so in an entirely disarrayed and arbitrary manner. The totalitarian system did not permit people to develop such skills; they were considered dangerous, because democratic."
Initiatives in the health field, as elsewhere, are stymied at each step by all kinds of bureaucratic, and what the Poles themselves refer to as "characteristically Polish," factors. The bureaucratic situation in the Ministry of Health is indeed so distressing that a visitor can only laugh at the outrageousness of it all. And, unfortunately, Stalinist ghosts still haunt the splendid nineteenth century palace in Warsaw's old town that houses the ministry. Those who helped run the health service into the ground still hold many powerful positions. The Chamber of Physicians (Poland's equivalent of the General Medical Council), for example, is still virtually controlled by members of the former nomenklatura, who may consider they have more to lose than to gain from further changes.

As regards the infamous "Polish factor," every visitor to Poland is, of necessity, referred to the history books for an explanation of the country's current distress. For Poland lies at the crossroads of Europe, and its spirit has been formed and deformed by the cataclysmic pressures of a millenium of continental madness. Centuries of oppression have therefore left the Poles with very little experience of government, negotiation, or leadership, and yet they have a tremendous ability to mobilise in times of crisis. Moreover, they are a highly individualistic people: every Pole has a different opinion on everything, and considers it imperative it be known. Inspiration and panache are held in high esteem; to be correct and dull is considered a horrid misfortune. They possess enormous vision and energy, but these energies often spill over in a disorganised, sometimes even disastrous way. Consequently, meetings, conferences, etc, often dissolve into chaos. As one visiting World Health Organisation consultant remarked to me: "The Poles must be restrained, they have too many ideas." Poland's history is, indeed, extraordinarily unhappy, and that unhappiness seems to permeate its modern day consciousness in a very tangible way. But they really cannot, as is their wont, put so much of what ails their health service down to the fact that Roosevelt sold them down the river at Yalta.

\section{Strong emotions}

One winter's day, the Polish deputy minister of health and I drove halfway across Poland to a meeting of chief sanitary inspectors from Poland's 49 provinces. We stopped for lunch in a village 100 miles south of Warsaw, and a hundred years away from 1991. The openings provided by the postcommunist order have turned the streets into a continuous market place, and life into a bit of a nightmare for these pioneers of public health, who are having to battle with the consequences of free enterprise bursting out all over. Unfortunately, Poland has become something of a dumping ground for substandard foreign food imports. Parliament is already overwhelmed and unable to keep up with legislation in this field, while regional public health departments hardly have the resources to keep up with vaccination programmes, let alone keep tabs on entrepreneurial Polish peasants turning out sausages in their back yards and then setting up shop by the road side. After a while the horror stories the sanitary inspectors were telling one another of what had been found inside some of these sausages, jars of pickled mushrooms, etc, and of milk from obviously leukaemic cows finding its way on to shop shelves, began to run together in my head. But their man from Czestochowa, home of Poland's Black Madonna, had a happy story: "Two million pilgrims we had, when the Pope came to visit last June, and not a single outbreak of diarrhoea. ... And, what's more, I didn't even have to ban the sale of ice cream."

At cocktails that evening, I was assailed by the 


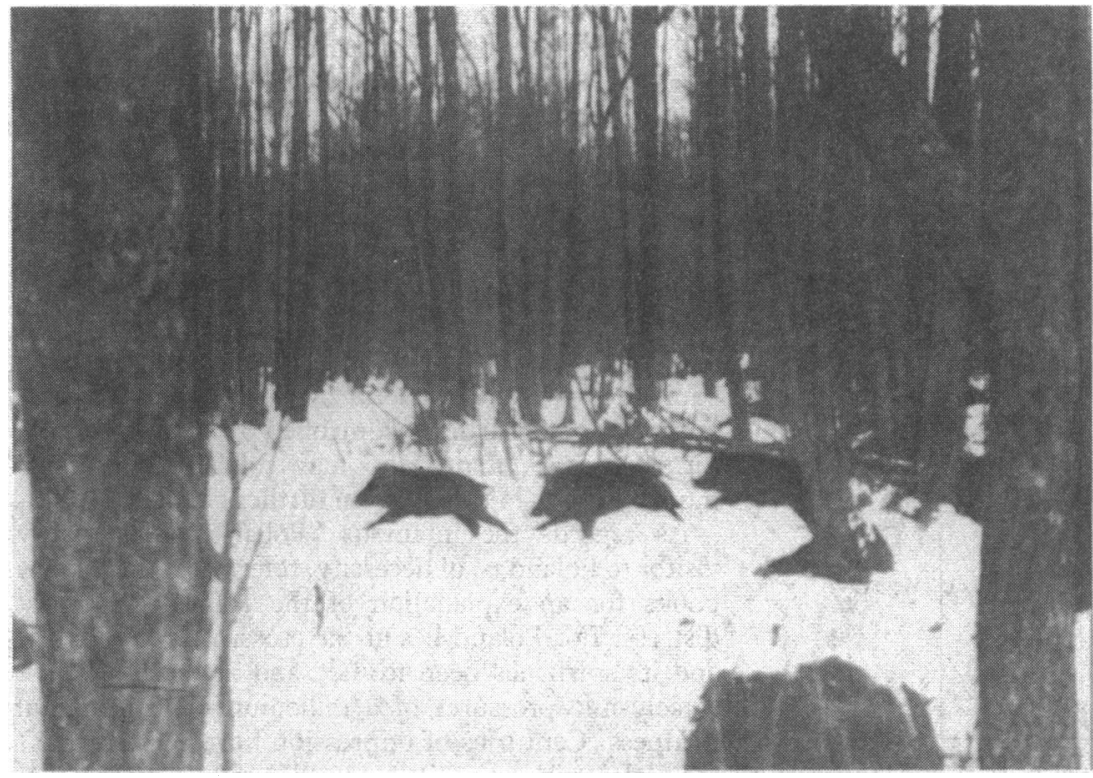

Wild boar in the Augustow forest, northeastern Poland
Lithuanian minister of health, a burly, genial epidemiologist. "I am here because we in Lithuania are looking to Poland, our neighbour and ancient ally, for an example for our health service," he told me. "Tomorrow I return to Vilnius." He paused. "Would you do us the honour of coming to write about our health service too? There's plenty of room in my car." I declined regretfully; he was wonderful company at dinner.

The next day found us in Wroclaw, Lower Silesia's historic capital, where I was shown around the maternity wing of a local hospital. A curious feature of the Polish maternity system is that new mothers are forbidden to see their husbands or relatives at any time during their hospital stay. Ministry of Health officials upheld this custom as an instance of Poland's strict hygienic precautions in hospitals. Women have little or nothing to say about the conduct of their labour. The treatment is invariably rough, impersonal, crass, as in a production line. But my most vivid impressions of all concern the lack of warmth or personal attention in these maternity wards, in which I never saw a sign of women's practical or emotional needs being taken into account: no personal effect such as a nightgown or slippers is permitted, no flower or card is allowed to taint Polish maternity wards' supposed "sterility." I seldom saw a smile or heard a happy voice in these institutions.

We continued our journey northwestwards to Zielona Gora, near Poland's border with Germany, where the minister opened Poland's first national conference on sex education (a suitable euphemism, which I now forget, was found for its official title). By coffee time, however, I was bored and sneaked out in search of our driver, who needed little persuasion to take me mushrooming (a favourite national pastime) in the beautiful forests surrounding the town. "Bison, lynx, and boar live here," the minister had told me as we had driven through. "And bears and storks and fish eagles," his driver had added. These two never missed an opportunity to draw their English guest's attention to the wealth of their nation. We filled the car boot with mushrooms and I returned to the conference hall trailing burr-like fragments, half a dozen yellow apples concealed in my ample handbag, just in time to witness the meeting erupt into impassioned chaos. That evening I ventured to ask the minister why Poles did not try to control their feelings in such situations. "What do you mean?" he retorted angrily, as if the idea had been proffered by a robot. "How can we do that? They are our feelings." Thus I learnt that true Slavs suffer their emotions as if they were forces of nature, winds and storms and volcanic eruptions. They cannot imagine tampering with them, for they are the most authentic part of them.

\section{Sick but passionate}

"So what is your diagnosis on the Polish health service after three months in our country, Dr Chopin?" the amiable journalist pressed me. "Third or Fourth World health care?" I wished fervently I had not been so bold as to agree to the interview as her tape recorder whirred menacingly on the table between us. I managed to avoid committing myself by making a feeble joke about the English remaining an underdeveloped nation too-in passion. She liked that.

My tour of the Polish health service had been an extraordinary journey, both professionally and personally. I was profoundly depressed by the shocking vastness of the damage done by 45 years of communism to the health of the Polish people, and to their psyche. Equally, I was enormously inspired by the sense of basic values which survives, impressed by their extraordinary initiative, by their blissful lack of cynicism, so fashionable in the West. And although the Poles are living in an epoch rife with problems and perils, life there is certainly not boring.

I would like to thank the many people all over Poland who were so helpful to me in researching these articles. I am indebted, in particular, to Professor Andrzej Wojtczak of the Medical Centre for Postgraduate Education, Warsaw; Dr Zbigniew Halat, deputy minister of health, and Mr Piotr Jaworski, his invaluable assistant; to the World Health Organisation team from Copenhagen-Dr Franz Staugaard, Dr Ilie Marcu, Dr Allan Juhl, and Ms Katinka de Vries; and, above all, to my friend Michael Slattery, who encouraged me to undertake this project and who died of an AIDS related illness while I was in Poland.

1 Foster DP, Józan P. Health in eastern Europe. Lancet 1990;335:458-60.

\section{ANY QUESTIONS}

What is the most appropriate contraception for a 22 year old woman who gives a good history of recurrent focal migraine (once every two to four weeks) since early childhood? I am particularly interested in the appropriateness of long acting depot progestogen (Depo-Provera).

In view of the lack of information about the patient's parity, marital state, and likelihood of compliance it is difficult to give a definite answer. As with many contraceptive problems so much depends on the individual patient and her motivation and ability to comply effectively with the recommended method.
The combined pill is definitely contraindicated, and the history of recurrent focal migraine is a relative contraindication to the progestogen only pill and DepoProvera. Because of the long term effect of Depo-Provera the progestogen only pill would be preferable if the patient was a reliable pill taker as it could be stopped if there was an aggravation of the focal migraine.

If she is an intelligent, well motivated patient a barrier method is the first choice. If she is unlikely to comply with use of a barrier method a progestogen only method should be recommended. - ANN JAMES, senior clinical medical officer in family planning, Dundee 